\title{
The Relationship Between the Online Learning Prosess in Early Chilhood and the Language Development of Pre School
}

\author{
Faizah Suci Damayanti ${ }^{1}$, Zuriati ${ }^{2}$, Intan Parulian Tiurma Roosleyn ${ }^{3}$ \\ 1,2,3 Nursing Program, University Binawan, Jakarta
}

\section{ARTICLE INFO}

Article history:

DOI:

10.30595/pshms.v2i.249

Submitted:

December 6, 2021

Accepted:

January 21, 2022

Published:

January 26, 2022

Keywords:

Online learning; early childhood; language development

\begin{abstract}
Language development is a combination of social interaction, emotional development, intellectual ability, and physical and motor development. However, the development of language in each individual child is different depending on neurological abilities and language development which can affect the stages of language development. Thus, this study aims to determine the implementation of online learning during the Covid-19 case study at TKIT Chiara Depok on the development of preschool language and to find out the inhibiting factors for learning during the Covid-19 period at TKIT Chiara Depok. This study uses descriptive analytic by using a cross sectional design. The population in this study were all parents who have preschool children at TKIT Chiara Depok, with a total of 56 respondents, by performing total sampling, collecting data for the online learning process and language development of preschool children using questionnaires and data processing with coding and analysis. data using the Chi-Square correlation statistical test. The results obtained as many as $78.6 \%$ have a good learning process using online methods, while the language development of preschool children is good about $80.4 \%$. There is a moderate positive relationship with $p$-value $=0.000(p<0.05)$ so that there is a relationship between the online learning process and language development. The conclusion in this study is that there is a relationship between the online learning process and the development of preschool language. With this research, the learning process in the online method that is good in its implementation and preparation will improve the development of good language in preschool children.
\end{abstract}

This work is licensed under a Creative Commons Attribution 4.0 International License.

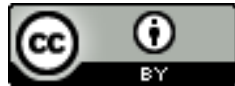

Corresponding Author:

Zuriati,

Nursing Program, University Binawan, Jakarta

Email: zuriati3781@gmail.com

\section{INTRODUCTION}

The process of learning from home through online learning ideally can still accommodate students' learning needs to develop talents and interests in accordance with their level of education. Therefore, to overcome this, educator readiness, appropriate curriculum, availability of learning resources, the stable of devices and networks so that communication between learners and educators can be effective. In fact, the current condition of online learning cannot be seen as an ideal condition because there are still various obstacles faced. These obstacles are also a challenge in the implementation of online learning considering that the implementation of online learning is a must so that educational activities can still be carried out in the midst of the current Covid-19 pandemic. Obstacles faced in the implementation of online learning include related to human resource readiness, lack of clear direction of local governments, the lack of proper curriculum, and limited facilities as well as the infrastructure, especially the minimum support of technology and internet networks. Human resource readiness including educators (teachers and lecturers), learners, and parental support is the most important part in the implementation of online learning. [3]

Online learning itself can be understood as a formal education organized by students and educators (teachers) are in separate locations so that it requires an interactive telecommunication system to connect 
both educators and students. Moreover, it also connects the various resources needed in it. [8] The most advantage of online learning is all levels of society anywhere in Indonesia can follow this program. Online learning provides effective learning methods, such as practicing with related feedback, combining collaboration activities with self-study, personalization of learning based on the needs of students who use simulations and games. [10]

Online learning also has the disadvantage of lack of internet access for some children who come from lower middle economic class families, resulting in the difficulty of performing the learning system. Teachers, students, and parents are forced to adapt quickly to this method. In the midst of a situation like this, online methods are one of the most appropriate solutions to do. However, the lack of technological knowledge of teachers, students, and parents is one of the problems of applying this online method. Parents who do not have good knowledge of technology can trigger problems, one of which is stress. [14]

\section{METHOD}

The research method used in this study is a correlative descriptive quantitative method using a cross sectional approach. The sample of this study is all students at TKIT Chiara Depok who follow the online method which numbers 56 preschool-age students instruments using the Guttman Scale with Chi-Square Test Statistic

To determine the use of the mean and median, first we need to test the normality test. Then, if the result of normality test is the sig result of 0.000 or less than 0.5 indicates the data is abnormally distributed. If the sig data is 0.5 it means we can use the mean because the mean is used for normal data. If it is not normal, then we can use the median. The process in online learning is divided into 2 categories, namely: good if the number of online learning scores $\geq$ the median score value of 15 , less good if the number of online learning scores < the median score value of 15 . Preschooler language development is divided into 2 categories, namely: good if the number of preschooler language development scores $\geq$ a median score of 15 , less good if the number of preschooler language development scores < a median score of 15 .

\section{RESULT AND DISCUSSIONS}

3.1.Univariat

Tabel 1.FrequencyDistributionofthecharacteristics respondents at TKIT Chiara Depok

\begin{tabular}{lcc}
\hline Characteristics of Respondents & Frequency & Percentage \\
\hline Age & 29 & $51.8 \%$ \\
4-5 years old & 27 & $48.2 \%$ \\
6-7 years old & & \\
& & \\
Gender & 26 & $46.4 \%$ \\
Boy & 30 & $53.6 \%$ \\
Girl & & \\
\hline Total & 56 & $100 \%$ \\
\hline
\end{tabular}

Basedontable 1 above, itisknownthatmostoftherespondents are girl, namely30 (53.6\%) respondents, andthe age dominated are 4-5 years old, namely 29 (51.8\%) ofrespondents.

Table 2.FrequencyDistributionofProcess in Online Learning and Language Development at TKIT Chiara Depok

\begin{tabular}{lcc}
\hline Variables & Frequency & Percentage \\
\hline $\begin{array}{l}\text { Process in Online } \\
\text { learning }\end{array}$ & \\
$\quad$ Good & 44 & \\
$\quad$ Less Good & 12 & $78.6 \%$ \\
& & $21.4 \%$ \\
Language Development & & \\
$\quad$ Good & 45 & $80.4 \%$ \\
$\quad$ Less Good & 11 & $19.6 \%$ \\
\end{tabular}


Based on table 2, for the process in online learning, the results found that respondents are dominated by the process in online learning is good that either has a percentage of $78.6 \%$ or 44 respondents. For the preschool language development found that respondents dominated by the preschool language development is good which had a percentage of $80.4 \%$ or 45 respondents.

\subsection{Bivariat}

Table 3. Relationship between Process in Online Learning and Language Development at TKIT Chiara

\begin{tabular}{|c|c|c|c|c|c|c|}
\hline \multirow{2}{*}{ Variable } & \multicolumn{4}{|c|}{ The Language Development } & \multirow[t]{2}{*}{ Total } & \multirow[b]{2}{*}{ p-value } \\
\hline & Good & Percentage & Less Good & Percentage & & \\
\hline $\begin{array}{l}\text { The Online } \\
\text { Learning }\end{array}$ & & & & & & \\
\hline Process & 40 & $90.9 \%$ & 4 & $9.1 \%$ & $44(100 \%)$ & 0,000 \\
\hline $\begin{array}{l}\text { Good } \\
\text { Less Good }\end{array}$ & 5 & $41.7 \%$ & 7 & $58.3 \%$ & $12(100 \%)$ & \\
\hline
\end{tabular}

Based on table 3, it shows that the results of the chi square calculation of the relationship between process in online learning and language development for preschool children at TKIT Chiara Depok obtained $\mathrm{p}$ value $0.000<0.05$ which means that it is significant and $\mathrm{Ha}$ is accepted. This means that there is a relationship between the online learning process and language development at TKIT Chiara Depok. There are 40 preschoolers who good in the online learning process and also good in the language development $(90.9 \%)$. However, there is also 7 preschoolers who are at less good category in learning process as well as less good at the language development $(58.3 \%)$.

3.3 The relationship between the process in online learning in early childhood and the language development

The results of this study showed that the good online learning process experienced good language development as many as 40 respondents $(90.9 \%)$ and a good online learning process experienced poor (less good) language development as much as 4 respondents $(9.1 \%)$. But there are still respondents with an online learning process that is not good experiencing poor (less good) language development as many as 7 respondents $(58.3 \%)$. Chi-Square statistical test results obtained a value of p-Value $=0.000(\mathrm{p}<0.050)$ meaning Ho was rejected and Ha accepted which means there is a relationship of the online learning process with the language development of preschoolers.

This research is supported by Ni Ketut [4] that there are research results on the use of TAKUTA media (syllable cards) in video-based online learning environments can improve language skills in children where the average cycle I obtained percentage $44.88 \%$ and the average cycle II obtained $61.84 \%$ with good category. It is characterized that the implementation of TAKUTA media use can improve children's language skills in Widiatmika's kindergarten. This is in line with the research of Jauharotur, Destita, and Ayu. [13] The results showed the impact of gadget use during the Covid-19 pandemic negatively affect language development and social development in children aged 5-6 years with an influence of $25.3 \%$. This can be seen from the t-test value obtained $0,000<0.05$, so the results are significant. For the magnitude of negative influences of 0.767 and 0.127 evidenced results from coefficient.

This research is supported by Brilianti, Tri, and Siti [17] that there are research results in accordance with expectations before treatment and after treatment. There was an increase in results of $42.0 \%$ in the category of good language development and as much as $10.0 \%$ with categorical language development that is not good. This is due to the results of storytelling stimulation with finger puppets that are done online. This approach can improve the language development of preschoolers in RA Mambaul Huda Puri District of Mojokerto Regency. Story telling stimulation activities that are done repeatedly in children, can train focus and concentration in children. This research is supported by Kentri [15] that there is a significant relationship between the process of online learning in early childhood and cognitive development and preschool language at TKIT Insan with a value of $\mathrm{P}$ value of $0.000<0.05$. This is not a reason to get high results, although in its implementation there are disadvantages found.This is because there is no other choice but to optimize online learning, due to the impact of this pandemic. Technology is what helps teachers and parents to still be able to develop language in children.

Based on the results of research, theory, and related research, it can be concluded that there is a connection between the online learning process and the development of children's language. It is clear that 
preschoolers are important to get the right learning process to improve their language and cognitive development. Language development is also one of the important developments for children to get. So that the right online learning process both preparation and implementation greatly impact the achievement of child development.

\section{CONCLUSIONS}

Based on the results of research on "Relationships of the Process In Online Learning In Early Childhood With Preschool Language Development At TKIT Chiara Depok" it can be concluded that the majority of processes in online learning are good $(78.6 \%)$, the majority of preschooler language development are good $(80.4 \%)$. There is a relationship between the online method learning process in early childhood with the development of preschoolers' language at TKIT Chiara Depok with p-value $=0.000$.

\section{Acknowledgements}

Thank you to Allah SWT, both parents and all comrades in arms who have helped from beginning to end.

\section{REFERENCES}

[1] Abiyoga, "Faktor-faktor Yang Berhubungan Dengan Kejadian Gout Pada Lansia Di Wilayah Kerja Puskesmas Situraja Tahun 2014," Jurnal Darul Azhar, vol. 2, no. 1, p. 47-56, 2017.

[2] M. Katuuk, "Hubungan Kemunduran Fisiologis Dengan Tingkat Stres Pada Lanjut Usia Di Puskesmas Kakaskasen Kecamatan Tomohon Utara,” Jurnal Keperawatan, vol. 6, no. 1, 2018.

[3] Risdianto, "Hubungan Dukungan Sosial dengan Kualitas Hidup Lanjut Usia di Desa Kembang Kuning Cepogo Boyolali.," Skripsi Fakultas Ilmu Kesehatan Universitas Muhammadiyah Surakarta, tidak dipublikasikan, Surakarta, 2009.

[4] Nugroho, Keperawatan Gerontik \& Geriatrik, 3 penyunt., Jakarta: EGC, 2008.

[5] S. Rohaediet al., "Tingkat Kemandirian Lansia Dalam Activities Daily," Pendidikan Keperawatan Indonesia, vol. 2, no. 1, p. 17, 2016.

[6] Priyoto, Teori Sikap \& Perilaku dalam Kesehatan, Yogyakarta: Nuha Medika, 2014.

[7] T. Y, "General Self Efficacy in Elderly Living in Rest Homes. Tehran. Iran," Journal of Nursing.

[8] E. Irawan dan F. Amelia, "Hubungan Self Efficacy Dengan Perawatan Diri Lansia Hipertensi," vol. 2, p. 130-139, 2017.

[9] M. Heidari dan M. ghodusi, "Comparative Self Efficacy in Elderly and Non Elderly ResidentsOf Family and Nursing Home in Shahrekord. Shahrekord.," Quarterly Journal of Geriatric Nursing, 2015.

[10] Nursalam, Metedologi penelitian ilmu keperawatan, 4 penyunt., Jakarta: Salemba Medika, 2015.

[11] A. Dwi, Arifianto dan Auliazardh, "Faktor faktor yang berhubungan dengan kemandirian activity of daily living ADL pada pasien post stroke di rehabilitasi medik RSUD Tuggurejo Semarang," Jurnal NERS Widya Husada, vol. 3, no. 1, 2016.

[12] Purwanto, Psikologi Pendidikan, Bandung: PT Remaja Rosdakarya, 2017.

[13] Gufron, Teori-Teori Psikologi, Ar-Ruzz Media, 2010.

[14] K. Putri, "Pengaruh Motivasi , Aktifitas dan Pemenuhan Tugas Pengembangan Terhadap Kepuasan Hidup Lansia Duda dan Janda,” IPB, BOGOR, 2015.

[15] V. Paskalini, "Hubungan Dukungan Sosial dan Motivasi Dengan Perawatan Mandiri Pada Pasien Diabetes Melitus Tipe 2 di Poliklinik Penyakit Penyakit dalam RSUD Nokopindo Toli Toli,” vol. 5, no. $1,2017$.

[16] . J. G. Kim, K. H. Moon, E. S. Lim dan J. H. Yoo, “[1 A Study on IADL, Stress and Motivation on Healthy Lifestyle among Elderly People with Arthritis.," Journal of the Korea Academia-Industrial Cooperation Society, vol. 17, no. 3, p. 209-217, 2016.

[17] D. Malida, "Faktor Yang Mempengaruhi Tingkat Kemandirian Lansia Dalam Melakukan Aktifitas Kehidupan Sehari - hari Di Panti Sosial Tresna Werdha Budi Luhur Kota Jambi,” Jambi, 2011.

[18] J. Doumit dan R. Nasser, "Quality of life and wellbeing of the elderly in Lebanese nursing homes.," International Journal of Health Care Quality Assurance, vol. 23, no. 1, p. 72-93, 2010. 